\title{
Evaluasi Jamu untuk Terapi Komplementer pada Pasien COVID-19 di Kabupaten Bondowoso
}

\author{
Siti Mudaliana ${ }^{1}$, Rasmono ${ }^{2}$, Dyaninta Yudhiarini ${ }^{1}$, Retno Indriatie $1^{1}$ dan Selvy Anggraeni ${ }^{1}$ \\ ${ }^{1}$ UPT Laboratorium Herbal Materia Medica Batu - Dinas Kesehatan Provinsi Jawa Timur, Jl. Lahor no. 87 Kota Batu, Jawa Timur, \\ Indonesia 65313 \\ 2 P4TO - Dinas Kesehatan Kabupaten Bondowoso, Jl. Imam Bonjol No.13, Kabupaten Bondowoso, Jawa Timur Indonesia 68217
}

\author{
Reception date of the manuscript: 30 November 2020 \\ Acceptance date of the manuscript: 3 Desember 2021 \\ Publication date: 31 Desember 2021
}

\begin{abstract}
The large number of covid-19 incidence in Bondowoso Regency led to the issuance on the use of local wisdom to help overcome it. P4TO Bondowoso District Health Office then issued a herbal concoction as a complementary therapy for Covid-19 patients who are being treated in hospital. This study aims to examine the quality of the herbs used in this complementary therapy. To test the quality, the organoleptic test, moisture content, phytochemical content, antioxidant, microbial contamination examination, and antibacterial activity of this herbal, which were consisting temu mangga, rosella, cinnamon, secang, and pandan suji were carried out. The test showed the consistency of organoleptic, while the moisture content was above the required value, which was $10 \%$. The phytochemical content test quantitatively showed that the herbal medicine contained flavonoids and alkaloids, with total flavonoids, total phenols, and IC50 values, were $1.86 ; 31.26 \mathrm{mg} /$ gram and $8.57 \mathrm{ppm}$ respectively. For microbiological testing, it is known that there is no significant microbial contamination. Antibacterial activity testing showed no antibacterial activity. Thus, it can be concluded that the anti-corona herbal medicine used as a complementary therapy in Bondowoso Regency is of good quality and has a high antioxidant value.
\end{abstract}

Keywords—anti-corona, antibacteria, antioxidant, herbal, quality.

\begin{abstract}
Abstrak- Banyaknya pasien covid-19 di Kabupaten Bondowoso menyebabkan dikeluarkannya edaran tentang pemanfaatan kearifan lokal untuk membantu mengatasinya. P4TO Dinas Kesehatan Kabupaten Bondowoso kemudian mengeluarkan ramuan jamu sebagai terapi komplementer untuk pasien covid-19 yang sedang dirawat di rumah sakit. Penelitian ini bertujuan untuk menguji kualitas jamu yang digunakan pada terapi komplementer tersebut. Untuk pengujian kualitas dilakukan uji organoleptis, kadar air, kandungan fitokimia, kadar antioksidan, pemeriksaan cemaran mikroba, dan aktivitas antibakteri dari ramuan jamu yang terdiri dari temu mangga, rosela, kayu manis, secang, dan pandan suji. Hasil pengujian menunjukkan konsistensi organoleptis, sedangkan kadar air di atas nilai yang dipersyaratkan, yaitu $10 \%$. Pengujian kandungan fitokimia secara kuantitatif menunjukkan jamu tersebut mengandung flavonoid dan alkaloid, dengan total flavonoid, total fenol, dan nilai IC50 hasil uji DPPH berturut-turut adalah 1,86; 31,26 mg/gram dan 8,57 ppm. Untuk pengujian mikrobiologi diketahui tidak ada cemaran mikroba yang berarti. Pengujian aktivitas antibakteri menunjukkan tidak ada aktivitas antibakteri. Dengan demikian, dapat disimpulkan bahwa "jamu anti-corona" yang digunakan sebagai terapi komplementer di Kabupaten Bondowoso secara kualitas bagus dan memiliki nilai antioksidan yang tinggi.
\end{abstract}

Kata Kunci-anti-corona, antibakteri, antioksidan, jamu, kualitas.

\section{Pendahuluan}

Saat ini, jenis virus korona baru telah teridentifikasi dan dinamai 2019 novel coronavirus (2019-nCoV atau kemudian disebut SARS-CoV 2 yang menyebabkan penyakit yang disebut COVID-19, serta menjadi pandemi global, termasuk di Indonesia. Infeksi pertama kali diidentifikasi di Wuhan, China, sebelum terdeteksi di tempat lainnya. Wabah tersebut dinyatakan sebagai darurat kesehatan yang menjadi perhatian internasional oleh WHO pada 30 Januari 2020 (Novel Co-

Penulis koresponden: Siti Mudaliana, E-mail: mudaliana@gmail.com ronavirus (2019-nCoV) Situation Report-1, 2020). COVID19 ditandai dengan gejala mirip flu termasuk demam, batuk, sindrom gangguan pernapasan akut yang parah, dan dalam beberapa kasus kematian (Huang et al., 2020). Sampai awal Oktober 2020, dilaporkan lebih dari 35 juta kasus global. Dari angka tersebut Indonesia menyumbang 303.498 kasus, dengan 11.151 kematian. Dalam situasi ini, pencegahan dan pengobatan yang efektif sangat diperlukan.

Dari 300 ribu lebih kasus di Jawa Timur, sekitar 700 kasus ditemukan di Kabupaten Bondowoso (. Dengan angka peningkatan yang relatif signifikan dari hari ke hari dan keterbatasan fasilitas serta tenaga kesehatan, maka Bupati Kabupaten Bondowoso mengeluarkan himbauan untuk peman- 
faatan kearifan lokal demi mengatasi pandemi. Salah satu hal yang dilakukan, yaitu penggunaan herbal / jamu sebagai terapi komplementer, terutama pada pasien COVID-19 dengan gejala ringan. Oleh karena kondisi darurat, sehingga jamu yang digunakan biasanya tanpa melewati uji mutu, padahal pasien COVID-19 seharusnya tidak diberikan "beban" lebih berat agar sistem imunnya tidak bekerja lebih keras lagi. Oleh sebab itu, penelitian ini dilakukan untuk mengetahui kualitas jamu yang digunakan sebagai terapi komplementer pada pasien COVID-19 di Kabupaten Bondowoso, serta untuk memastikan bahwa ramuan yang digunakan mempunyai khasiat untuk meningkatkan sistem imun dengan pengujian kandungan antioksidan. Selain itu, juga dilakukan pengujian aktivitas antibakteri, di mana ramuan jamu yang digunakan diharapkan dapat menekan pertumbuhan bakteri-bakteri patogen, sehingga tidak memperparah kondisi pasien COVID19 tersebut.

\section{BAHAN DAN METODE}

\section{Bahan dan Alat}

Bahan yang digunakan dalam penelitian adalah serbuk

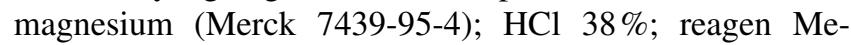
yer, reagen Dragendrof (Merck 1.02035); reagen Bouchardat; FeCl3; DPPH (2,2-diphenyl-1-picrylhydrazyl); FolinCiocalteu (Merck 1.09001); quercetin (Sigma-Aldrich Q4951); alumunium klorida; asam galat (Merck 8.42649); media PCA (plate count agar, Merck 1.05463), PDA (potato dextrose agar, Merck 1.10130), EMBA (eosin methylene blue agar, Oxoid CM0069), SSA (Salmonella Shigella agar, Merck 1.07067), MacCONKEY agar (Oxoid CM0007), BHI (Merck 1.10493); MHA (Mueller-Hinton agar; Oxoid CM 0337); kultur bakteri Escherichia coli ATCC 25922; Staphylococcus aureus ATCC 25923; Salmonella typhi; Vibrio cholerae; dan Bacillus subtillis isolat FK-Universitas Brawijaya. Peralatan yang digunakan dalam penelitian ini adalah moisture balance (Ohaus MB120); spektrofotometer UV-Vis (Jasco V-730); inkubator (Lab companion IB-11E); dan colony counter (Interscience Scan300).

\section{Metode}

\section{Preparasi Sampel}

Sampel dengan komposisi sebagai berikut: 10 gram rimpang temu mangga (Curcuma manga), 3 gram bunga rosella (Hibiscus sabdariffa), 3 gram daun pandan suji (Dracaena angustifolia), 5 gram kayu secang (Caesalpinia sappan), dan 5 gram kulit batang kayu manis (Cinnamommum burmanii). Kadar air diukur dengan menggunakan alat moisture balance. Selanjutnya dilakukan proses ekstraksi. Ekstrak dibuat mengikuti prosedur yang tertera pada kemasan, yaitu dengan cara satu kemasan ramuan dimasukkan dalam 4 (empat) gelas air mendidih dan dimasak dengan api kecil selama 15 menit atau sampai air tersisa setengahnya. Proses pemasakan tidak boleh dilakukan pada wadah yang terbuat dari alumunium. Ekstrak kemudian disaring dan siap digunakan.

Ekstrak yang sudah siap digunakan kemudian diuji untuk mengetahui adanya flavonoid, alkaloid, saponin, dan tanin menggunakan prosedur standar seperti dijelaskan sebelumnya (Harborne, 1973). Selanjutnya, dilakukan pengujian kadar total flavonoid, total fenol, dan nilai IC50 menggunakan metode DPPH untuk mengetahui aktivitas antioksidan ramuan tersebut. Selain itu, juga dilakukan uji mikrobiologi untuk mengetahui cemaran mikroba, serta uji aktivitas antibakteri.

\section{Skrining Fitokimia}

Untuk skrining flavonoida, ekstrak ditambahkan $0,1 \mathrm{~g}$ magnesium powder dan 3 tetes $\mathrm{HCl} 38 \%$. Jika larutan berubah warna menjadi jingga hingga merah, maka positif mengandung flavonoid. Skrining alkaloida dilakukan dengan cara ekstrak dimasukkan ke dalam tiga tabung reaksi yang berbeda, kemudian masing-masing ditetesi dengan 3 tetes reagen Meyer, reagen Dragendrof dan reagen Bouchardat. Hasil positif ditunjukkan dengan adanya endapan larutan yang terbentuk di dasar tabung. Sedangkan, untuk skrining tanin dilakukan dengan memanaskan ekstrak kemudian ditambahkan $\mathrm{FeCl} 31 \%$. Hasil positif ditunjukkan dengan terbentuknya warna coklat kehijauan atau biru kehitaman. Uji saponin dilakukan dengan ekstrak dipanaskan dan dikocok kuat selama 1 menit, selanjutnya ditambahkan dengan 2 tetes $\mathrm{HCl}$ $38 \%$. Jika busa yang terbentuk tidak hilang setelah penambahan $\mathrm{HCl} 38 \%$, maka dapat dikatakan sampel mengandung saponin. Untuk pengujian kandungan terpenoid, sampel ditambahkan pereaksi Bouchardat 3 tetes, jika terbentuk warna jingga kecoklatan, maka menunjukkan adanya terpenoid.

\section{Uji Aktivitas Antioksidan}

Total fenol ekstrak ditentukan dengan menggunakan reagen Folin dan Ciocalteu, mengikuti metode yang dijelaskan oleh Singleton dan Rossi, dengan sedikit modifikasi (Singleton \& Rossi, 1965). Pembacaan sampel dan standar dibuat dengan menggunakan spektrofotometer UV-Vis pada panjang gelombang $765 \mathrm{~nm}$. Sampel uji $(0,2 \mathrm{~mL})$ dicampur dengan $0,6 \mathrm{~mL}$ air dan $0,2 \mathrm{~mL}$ reagen fenol Folin-Ciocalteu $(1: 1)$. Setelah 5 menit, $1 \mathrm{~mL}$ larutan natrium karbonat jenuh ( $8 \%$ b/v dalam air) ditambahkan ke dalam campuran dan volumenya dibuat hingga $3 \mathrm{~mL}$ dengan penambahan akuades. Reaksi disimpan dalam gelap selama 30 menit, kemudian absorbansi warna biru dari sampel yang berbeda diukur pada panjang gelombang $765 \mathrm{~nm}$.

Metode kolorimetri aluminium klorida digunakan untuk penentuan kandungan flavonoid total dari sampel Marinova et al. (2005); Chang et al. (2002). Untuk penentuan flavonoid total, quercetin digunakan untuk membuat kurva kalibrasi standar. Larutan stok kuersetin dibuat dengan melarutkan 5,0 mg kuersetin dalam 1,0 mL metanol, kemudian larutan standar kuersetin dibuat dengan pengenceran berseri menggunakan metanol (5-200 g / mL). Sejumlah 0,6 mL ekstrak quercetin standar yang diencerkan dicampur secara terpisah dengan 0,6 mL aluminium klorida $2 \%$. Setelah pencampuran, larutan diinkubasi selama 60 menit pada suhu kamar. Absorbansi campuran reaksi diukur terhadap blanko pada panjang gelombang $420 \mathrm{~nm}$ menggunakan spektrofotometer UV-Vis.

Aktivitas ekstrak tumbuhan untuk bereaksi langsung dengan dan mengatasi radikal bebas dievaluasi seperti yang dijelaskan sebelumnya Cheng et al. (2006). Larutan stok DPPH (100 M) disiapkan dalam etanol, kemudian diinkubasi di ruangan gelap selama 30 menit. Sampel diencerkan dalam etanol sesuai kebutuhan (pengenceran serial 1000; 500; 250; $125 ; 62,5 \mathrm{ppm})$. Campuran reaksi, berisi $1 \mathrm{~mL}$ larutan stok DPPH dan $1 \mathrm{~mL}$ sampel uji yang diencerkan, diinkubasi di ruangan gelap selama 30 menit. Absorbansi diukur pada panjang gelombang 516,5 nm menggunakan spektrofotometer UV-Vis. Asam galat digunakan sebagai kontrol positif. 
TABEL 1: HASIL UJI ORGANOLEPTIS RAMUAN JAMU YANG DIGUNAKAN SEBAGAI TERAPI KOMPLEMETER PADA PASIEN COVID-19 DI KABUPATEN BONDOWOSO

\begin{tabular}{llll}
\hline SIMPLISIA & BENTUK & RASA & AROMA \\
\hline Temu Mangga & $\begin{array}{l}\text { Berwarna putih kecoklatan, lembek, } \\
\text { liat, kurang kering. }\end{array}$ & Berakhiran pahit & $\begin{array}{l}\text { Terdapat bau asam khas } \\
\text { buah mangga }\end{array}$ \\
Rosella & $\begin{array}{l}\text { Berwarna merah marun, liat dan } \\
\text { cukup kering }\end{array}$ & Memiliki rasa asam & Bau asam khas rosella \\
Pandan Suji & $\begin{array}{l}\text { Berwarna hijau gelap, liat dan } \\
\text { kurang kering }\end{array}$ & Tidak memiliki rasa & Memiliki bau khas daun \\
Kayu Secang & $\begin{array}{l}\text { Berwarna jingga kecoklatan, liat dan } \\
\text { cukup kering }\end{array}$ & Tidak memiliki rasa & Tidak memiliki bau \\
Kayu Manis & Berwarna coklat tua, keras dan kering & Memili rasa khas kayu manis & Terdapat aroma khas kayu manis \\
\hline
\end{tabular}

TABEL 2: HASIL SKRINING FITOKIMIA, KADAR AIR, TOTAL FENOL, TOTAL FLAVONOIDA, DAN IC50 RAMUAN JAMU YANG DIGUNAKAN SEBAGAI TERAPI KOMPLEMETER PADA PASIEN COVID-19 DI KABUPATEN BONDOWOSO

\begin{tabular}{ll}
\hline Parameter & Hasil uji \\
\hline Kadar air & $11,47 \pm 0,74 \%$ \\
Uji flavonoida & $(+)$ \\
Uji alkaloida & $(+)$ \\
Uji tanin & $(-)$ \\
Uji terpenoid & $(-)$ \\
Uji saponin & $(-)$ \\
Total fenol & $31,26 \mathrm{mg} /$ gram sampel \\
Total flavonoida & $1,86 \mathrm{mg} /$ gram sampel \\
IC50 & $8,57 \mathrm{ppm}$ \\
\hline
\end{tabular}

TABEL 3: HaSil ATURAn Lipinski

\begin{tabular}{ll}
\hline Parameter & Hasil uji \\
\hline ALT & $3,8 \times 10^{\wedge} 5$ koloni/g \\
AKK & $6,3 \times 10^{\wedge} 2$ koloni/g \\
E.coli & $(-)$ \\
Salmonella & $(-)$ \\
Shigella & $(-)$ \\
\hline
\end{tabular}

\section{Uji Cemaran Mikroba}

Pengujian cemaran mikroba dilakukan melalui pengujian angka lempeng total (ALT), angka kapang/khamir (AKK), uji cemaran E. coli, Salmonella, dan Shigella.

Untuk uji ALT dan AKK, sebanyak 25 gram sampel dilarutkan dalam $225 \mathrm{ml}$ larutan $0,9 \% \mathrm{NaCl}$ steril, dan diaduk dengan batang pengaduk steril hingga homogen. Larutan ini dianggap sampel dengan pengenceran $10^{-1}$. Selanjutnya dilakukan pengenceran berseri $10^{-2}, 10^{-3}, 10^{-4}, 10^{-5}, 10^{-6}$ menggunakan pelarut $0,9 \% \mathrm{NaCl}$ steril. Selanjutnya masingmasing $1 \mathrm{ml}$ sampel dipipet ke dalam cawan Petri steril. Untuk pengujian ALT digunakan media kultur PCA (plate count agar) steril, sedangkan uji AKK digunakan PDA (potato dextrose agar), kemudian diinkubasi pada suhu $37^{\circ} \mathrm{C}$. Penghitungan koloni dilakukan setelah inkubasi $1 \times 24$ jam. Bila koloni belum mencapai angka 25 - 250 untuk uji ALT dan 10-150 untuk uji AKK, maka penghitungan dilakukan pada 24 jam berikutnya, dan seterusnya sampai maksimal hari ke-5. Penentuan jumlah koloni mengikuti aturan yang ditetapkan $\mathrm{Pu}-$ sat Pengujian Obat dan Makanan Nasional (MA PPOMN nomor 96/mik/00), serta dinyatakan dalam colony forming unit atau cfu/gram (Anonim, 2006).
Untuk pengujian cemaran E. coli diambil sebanyak $1 \mathrm{ml}$ dari larutan suspensi sampel pada pengenceran $10^{-1}$ dan $10^{-1}$ dengan metode tuang (pour plate) pada EMBA (eosin methylene blue agar). Selanjutnya diinkubasi pada suhu $35^{\circ} \mathrm{C}$ selama 24 jam. Pengamatan dilakukan terhadap koloni bakteri $E$. coli yang tumbuh berupa koloni berwarna hijau metalik dengan bintik hitam di bagian tengahnya. Hasil positif pada kemudian digores pada media MacConkey agar untuk konfirmasi. Sedangkan, untuk pengujian cemaran Salmonella dan Shigella dilakukan pengayaan dengan media BHI. Inkubasi dilakukan pada suhu $35^{\circ} \mathrm{C}$ selama 24 jam. Selanjutnya sebanyak $1 \mathrm{ml}$ dari larutan suspensi sampel pada pengenceran $10^{-1}$ dan $10^{-2}$ digores pada media SSA (salmonella Shigella agar). Selanjutnya diinkubasi pada suhu $35^{\circ} \mathrm{C}$ selama 24 jam.

\section{Uji Aktivitas Antibakteri}

Pengujian aktivitas antibakteri dilakukan dengan metode Kirby-Bauer dengan kertas cakram menggunakan bakteri, yaitu S. aureus; S. typhi, V. cholerae; B. subtillis; dan E. coli pada media Mueller-Hinton agar.

\section{HASIL}

Hasil uji organoleptis terhadap sampel menunjukkan konsistensi bentuk, rasa, dan aroma atau bau. Sedangkan, untuk pengujian susut pengeringan atau kadar air menunjukkan nilai yang lebih tinggi dari $10 \%$, yaitu rata-rata $11,47 \%$. Untuk kandungan fitokimia, dari uji kualitatif diketahui bahwa sampel mengandung senyawa-senyawa flavonoida dan alkaloida saja. Sampel diketahui tidak mengandung senyawa saponin, terpenoid, dan tanin. Sedangkan untuk uji aktivitas antioksidan menunjukkan bahwa sampel menunjukkan aktivitas antioksidan yang tinggi. Untuk uji cemaran mikroba, secara keseluruhan sampel tidak menunjukkan cemaran mikroba yang berarti atau sesuai dengan Peraturan Badan Pengawas Obat dan Makanan Nomor 32 tahun 2019 Tentang Persyaratan Keamanan dan Mutu Obat Tradisional. Uji lebih lanjut, yaitu uji aktivitas aktibakteri menghasilkan tidak adanya daya hambat yang terbentuk atau sampel tidak memiliki aktivitas antibakteri.

\section{Pembahasan}

Ramuan yang digunakan sebagai terapi komplementer pada pasien COVID-19 di Kabupaten Bondowoso terdiri dari 5 bahan, yaitu rimpang temu mangga, bunga rosella, daun pandan suji, kayu secang, dan kulit batang kayu manis. Mengikuti saran dari BPOM RI, jumlah bahan yang digunakan pada ramuan sebaiknya tidak lebih dari lima jenis untuk me- 
mudahkan stadarisasi bahan baku, seperti halnya penelitian tentang jamu sebagai terapi komplementer yang dilakukan sebelumnya. Astana, dkk (2018) menggunakan hanya 3 jenis bahan temu lawak, temu mangga dan meniran pada pasien HIV/AIDS, tetapi sudah menunjukkan hasil yang signifikan dalam peningkatan kualitas hidup pasien (Astana et al., 2018). Hasil uji organoleptis terhadap ramuan jamu menunjukkan hasil yang konsisten antar subjek dan antar pengulangan sampel, seperti pada tabel 1. Hanya saja, untuk kadar air masing-masing bahan lebih dari 10\% (tabel 2), padahal sesuai Peraturan Badan Pengawas Obat dan Makanan Nomor 32 tahun 2019 Tentang Persyaratan Keamanan dan Mutu Obat Tradisional kadar air seharusnya $\leq 10 \%$. Sedangkan untuk cemaran mikroba pada ramuan tersebut tidak melanggar persyaratan BPOM RI yang tertuang pada Peraturan BPOM Nomor 32 tahun 2019, di mana nilai ALT $5 \times 10^{7}$ koloni/g; AKK $5 \times 10^{5} \mathrm{koloni} / \mathrm{g}$; E.coli $10^{2} \mathrm{koloni} / \mathrm{g}$; serta tidak terindikasi tercemar Salmonella spp. maupun Shigella spp seperti ditunjukkan pada tabel 3.

Hasil skrining fitokimia dari ramuan jamu menunjukkan bahwa bahan-bahan tersebut mengandung flavonoida dan alkaloida, tetapi tidak mengandung tanin, terpenoid, dan saponin. Analisis lebih lanjut terhadap kandungan total fenol dan total flavonoida menghasilkan angka 31,26 dan 1,86 $\mathrm{mg} /$ gram sampel. Analisis dengan metode DPPH assay untuk antioksidan menunjukkan nilai IC50 yang relatif kecil, yaitu $8,57 \mathrm{ppm}$. Melihat hasil analisis fitokimia dapat dikatakan bahwa ramuan tersebut diperkirakan dapat membantu meningkatkan sistem imun pada pasien COVID-19 karena kandungan antioksidan yang cenderung tinggi. Diketahui bahwa flavonoida dan alkaloida mampu berperan sebagai antioksidan dalam tubuh Gul et al. (2017); Jiang et al. (2018); Agu \& Okolie (2017), sehingga diharapkan dapat membantu proses percepatan penyembuhan pasien, seperti diketahui bahwasanya antioksidan mampu mengikat radikal bebas yang merugikan tubuh (Brambilla et al., 2008; Bendich, 1990). Antioksidan dari ramuan ini didapatkan dari bahan-bahan yang digunakan seperti yang dijabarkan oleh penelitian-penelitian sebelumnya, yaitu temu mangga (A. Setyaningrum et al., 2013); pandan suji Adiwisastra (2014); rosella (Djaeni et al., 2017); secang (Febriyenti et al., 2018); dan kayu manis (Prasetyaningrum et al., 2012) mempunyai aktivitas antioksidan.

Hasil pengujian aktivias antibakteri menunjukkan bahwa ramuan ini tidak mempunyai kemampuan dalam menghambat pertumbuhan bakteri-bakteri patogen yang digunakan dalam penelitian ini. Padahal penggunaan tunggal beberapa bahan dalam ramuan ini diketahui memiliki aktivitas antibakteri, misal temu mangga yang mampu menghambat pertumbuhan bakteri E.coli (P. R. Sarjono \& Mulyani, 2007); kayu secang terhadap S.aureus, S. dysentriae, dan V. cholerae (Dianasari, 2009; Ni Made Gress Rakasari Nomer et al., 2019). Temu mangga yang dikombinasi dengan antinganting diketahui mampu menghambat pertumbuhan bakteri E.coli (Cahyaningrum \& Artini, 2018) atau kombinasi temu mangga dengan kayu secang yang ternyata mampu melawan pertumbuhan bakteri E.coli, Salmonella sp. dan Shigella sp. Uyo et al. (2018). Hal ini kemungkinan besar disebabkan oleh perbedaan jenis sediaan. Penelitian-penelitian sebelumnya menggunakan sediaan dari ekstrak etanol, sedangkan ekstrak yang digunakan pada penelitian ini menggunakan air dengan proses perebusan biasa yang kemungkinan suhunya terlalu tinggi sehingga merusak komponen fitokimia yang terdapat pada bahan. Seperti terlihat pada tabel 2, sampel yang digunakan tidak mengandung senyawa-senyawa yang berperan besar dalam melawan mikroba, di antaranya terpenoid, tanin dan saponin. Oleh sebab itu, sebaiknya digunakan proses yang standar agar kualitas ramuan tidak menurun, misalnya dilakukan dengan ekstraksi dan diedarkan dalam bentuk kapsul.

\section{KESIMPULAN}

Ramuan jamu yang digunakan berpontensi baik sebagai terapi komplementer pada pasien COVID-19 karena secara kualitas bagus, secara organoleptis konsisten dan tidak tercemar mikroba patogen. Ramuan ini berperan dari sisi membantu meningkatkan sistem imun pasien terkait dengan kandungan antioksidannya yang tinggi. Ramuan diketahui tidak mempunyai aktivitas antibakteri.

\section{UCAPAN TERIMA KASIH}

Ucapan terima kasih disampaikan kepada Ibu Fitria Rahmawati, S.Farm, Apt.; Ibu Dra. Elmi Mufidah, Apt., M.Kes.; dan seluruh staf Griya Sehat / P4TO Dinas Kesehatan Kabupaten Bondowoso.

\section{Daftar Pustaka}

A. Setyaningrum, MAM Andriani, \& Yani, F. (2013). POTENSI TEMU MANGGA (Curcuma mangga Val.) SEBAGAI MINUMAN FUNGSIONAL. J. Teknosains Pangan, 2(3), 27-33.

Adiwisastra, N. G. (2014). Pengujian Aktivitas Antioksidan Dan Penetapan Kadar Klorofil Total Pada Ekstrak Daun Suji (Pleomele Angustifolia Roxb.) Dan Functional Edible Film. Ph.D. thesis.

Agu, K. C., \& Okolie, P. N. (2017). Proximate composition, phytochemical analysis, and in vitro antioxidant potentials of extracts of Annona muricata (Soursop). Food Sci. Nutr., 5(5), 1029-1036.

Astana, P. R. W., Ardiyanto, D., \& Mana, T. A. (2018). Perubahan Kualitas Hidup dan Nilai CD4+ Pasien HIV/AIDS dengan Pemberian Ramuan Jamu Imunostimulan di Sragen. J. Farm. Klin. Indones., 7(4), 227-235.

Bendich, A. (1990). Antioxidant Nutrients and Immune Functions - Introduction. In Antioxid. Nutr. Immune Funct. Adv. Exp. Med. Biol.. Boston: Springer.

Brambilla, D., Mancuso, C., Scuderi, M. R., Bosco, P., Cantarella, G., Lempereur, L., Di Benedetto, G., Pezzino, S., $\&$ Bernardini, R. (2008). The role of antioxidant supplement in immune system, neoplastic, and neurodegenerative disorders: a point of view for an assessment of the risk/benefit profile. Nutr. J., 7(1), 29.

Cahyaningrum, P. L., \& Artini, N. P. R. (2018). UJI AKTIVITAS ANTIBAKTERI SERBUK INSTAN KOMBINASI TEMU MANGGA (CURCUMA MANGGA VAL.) DAN DAUN ANTING-ANTING (ACALYPHA INDICA L.). J. Kesehat. Terpadu, 2(1), 1-6.

Chang, C. C., Yang, M. H., Wen, H. M., \& Chern, J. C. (2002). Estimation of Total Flavonoid Content in Propolis 
by Two Complementary Colorimetric Methods. J. Food Drug Anal., 10, 178-182.

Cheng, Z., Moore, J., \& Yu, L. L. (2006). High-Throughput Relative DPPH Radical Scavenging Capacity Assay. J. Agric. Food Chem., 54(20), 7429-7436.

Dianasari, N. (2009). UJI AKTIVITAS ANTIBAKTERI EKSTRAK ETANOL KAYU SECANG (Caesalpinia sappan L.) TERHADAP Staphylococcus aureus DAN Shigella dysentriae SERTA BIOAUTOGRAFINYA. Ph.D. thesis.

Djaeni, M., Ariani, N., Hidayat, R., \& Utari, F. (2017). EKSTRAKSI ANTOSIANIN DARI KELOPAK BUNGA ROSELLA (HIBISCUS SABDARIFFA L.) BERBANTU ULTRASONIK: TINJAUAN AKTIVITAS ANTIOKSIDAN. J. Apl. Teknol. Pangan, 6(3), 148-151.

Febriyenti, F., Suharti, N., Lucida, H., Husni, E., \& Sedona, O. (2018). Karakterisasi dan Studi Aktivitas Antioksidan dari Ekstrak Etanol Secang (Caesalpinia sappan L.). $J$. Sains Farm. Klin., 5(1), 23-27.

Gul, R., Jan, S. U., Faridullah, S., Sherani, S., \& Jahan, N. (2017). Preliminary Phytochemical Screening, Quantitative Analysis of Alkaloids, and Antioxidant Activity of Crude Plant Extracts from $<\mathrm{i}>$ Ephedra intermedia $<$ i $>$ Indigenous to Balochistan. Sci. World J., 2017, 5873648.

Harborne, J. B. (1973). Phytochemical Methods: A Guide to Modern Techniques of Plant Analysis. Dordrecht: Springer, second edi ed.

Jiang, X.-L., Wang, L., Wang, E.-J., Zhang, G.-L., Chen, B., Wang, M.-K., \& Li, F. (2018). Flavonoid glycosides and alkaloids from the embryos of Nelumbo nucifera seeds and their antioxidant activity. Fitoterapia, 125, 184-190.

Marinova, D., Ribarova, F., \& Atanassova, M. (2005). Total phenolics and flavonoids in Bulgarian fruits and vegetables. J. Univ. Chem. Technol. Metall., 40, 255-260.

Ni Made Gress Rakasari Nomer, Duniaji, A. S., \& Nocianitri, K. A. (2019). KANDUNGAN SENYAWA FLAVONOID DAN ANTOSIANIN EKSTRAK KAYU SECANG (Caesalpinia sappan L.) SERTA AKTIVITAS ANTIBAKTERI TERHADAP Vibrio cholerae. J. Ilmu dan Teknol. Pangan, $8(2), 216-225$.

P. R. Sarjono, \& Mulyani, N. S. (2007). Aktivitas Antibakteri Rimpang Temu Putih (Curcuma mangga Vall). J. Sains Mat., 15(2), 89-93.

Prasetyaningrum, Utami, R., \& Anandito, R. K. (2012). AKTIVITAS ANTIOKSIDAN, TOTAL FENOL, DAN ANTIBAKTERI MINYAK ATSIRI DAN OLEORESIN KAYU MANIS (Cinnamomum burmannii). J. Teknosains Pangan, 1(1), 24-31.

Singleton, V. L., \& Rossi, J. A. (1965). Colorimetry of Total Phenolics with Phosphomolybdic-Phosphotungstic Acid Reagents. Am. J. Enol. Vitic., 16(3), 144 LP - 158.

Uyo, N., Tamat, S. R., \& Kosasih, K. (2018). Granul Ekstrak Kayu Secang (Caesalpinia sappan L.) dan Rimpang Temu Mangga (Curcuma mangga Val \& Zijp.) sebagai Antibakteri. J. Biol. Papua, 10(1), 11-16. 